\title{
Expansion of the southern limit of Vampyrodes caraccioli Thomas, 1889 (Chiroptera, Phyllostomidae) and first record for Santa Catarina state, southern Brazil
}

\author{
Sérgio Luiz Althoff, ${ }^{1}$ Bianca Tribess, ${ }^{1}$ Maria Júlia Reinert, ${ }^{1}$ Matheus A. R. Ferreira, ${ }^{1}$ Fernando \\ Carvalho ${ }^{2}$
}

1 Universidade Regional de Blumenau, Departamento de Ciências Naturais, CEP 89035-205, Blumenau, SC, Brazil. 2 Universidade do Extremo Sul Catarinense, Programa de Pós-Graduação em Ciências Ambientais, Laboratório de Zoologia e Ecologia de Vertebrados, CEP 80806-000, Criciúma, SC, Brazil.

Correspond author: Sérgio Luiz Althoff, slalthoff@gmail.com

\begin{abstract}
Three specimens of Vampyrodes caraccioli were collected in Corupá and São Bento do Sul, in Santa Catarina state, increasing its geographic distribution extension by $170 \mathrm{~km}$ south. These specimens also represent the first record for the species in Santa Catarina. The knowledge about bats in Santa Catarina has increased in recent years, showing the need of basic studies about richness and diversity in different regions.
\end{abstract}

\section{Key words}

Bats; Atlantic forest; geographic distribution; range extension; new record.

Citation: Althoff SL, Tribess B, Reinert MJ, Ferreira MAR, Carvalho F (2017) Expansion of the southern limit of Vampyrodes caraccioli Thomas, 1889 (Chiroptera, Phyllostomidae) and first record for Santa Catarina state, southern Brazil. Check List 13 (6): 871-877. https://oi . org $/ 10.15560 / 13.6 .871$

\section{Introduction}

The knowledge about the bat fauna has increased in the last two decades in Brazil, with specialized publications about the group (Reis et al. 2007, Peracchi et al. 2012, Nogueira et al. 2014), description of new species (e.g. Gregorin and Ditchfield 2005, Miranda et al. 2006, Nogueira et al. 2012, Dias et al. 2013, Feijó et al. 2015, Moratelli and Dias 2015), and reports of new records for several regions (e.g. Zortéa et al. 2013, Dias et al. 2016, Basílio et al. 2017), including the southern region of the country (e.g. Weber et al. 2006, Gazarini and Bernardi 2007, Miranda et al. 2007, Scultori et al. 2009a, b, c, Carvalho and Fabián 2011, Carvalho et al. in press). Addi- tionally, in the last 6 years the distribution of the genus Vampyrodes Thomas, 1900 has been expanded (Velazco et al. 2010, Velazco and Simmons 2011, Carvalho et al. 2014, Lopes et al. 2016).

Vampyrodes was considered for a long time as a monotypic genus (Gardner 2008a, Velazco et al. 2010), however, it is currently composed of 2 species: Vampyrodes major Allen, 1908 and Vampyrodes caraccioli (Thomas, 1889), both species overlapping in their areas of distribution in the northern part of South America, more specifically in Colombia (Velazco and Simmons 2011). Considering the variation on body size observed within the family Phyllostomidae, both species are considered as medium-sized bats, with forearm length ranging between 
$46.8 \mathrm{~mm}$ to $57.3 \mathrm{~mm}$ and weight from $25 \mathrm{~g}$ to $34 \mathrm{~g}$ (Willis et al. 1990, Gardner 2008a, Zortéa 2007), V. caraccioli being smaller than $V$. major (Velazco and Simmons 2011). The genus shows 4 facial stripes well pronounced and 1 on the dorsal region, extending from the top of the head until the uropatagium base (Zortéa 2007, Peracchi et al. 2012). Despite the similarities, the species are easily distinguished by external morphological characters, such as the length of dorsal pelage, uropatagium edge shape, and number and position of vibrissae (Velazco and Simmons 2011, Díaz et al. 2016).

Vampyrodes caraccioli is distributed in South America, with confirmed records for Colombia, Ecuador, Bolivia, Trinidad, Tobago, Venezuela, French Guiana, Suriname, Guyana, and Brazil (Velazco and Simmons 2011). In Brazil, the species has been reported to occur in Acre, Amazonas, Amapá, Bahia, Mato Grosso, Mato Grosso do Sul, Pará, Rio de Janeiro, São Paulo, and Paraná (Lopes et al. 2016), the last state considered the known austral limit of the species distribution (Carvalho et al. 2014). Vampyrodes. caraccioli is usually reported with small abundance in inventories (e.g Kalko and Handley 2001, Martins et al. 2006, 2011, Souza et al. 2015), compromising further information about its biology and ecology. The present note aims to report the expansion of the Southern limit distribution of Vampyrodes caraccioli and the first record for Santa Catarina state in southern Brazil.

\section{Methods}

The records here reported were obtained during samplings of bats in 2 areas in the north of Santa Catarina state, Brazil. Area I corresponds to the Reserva Particular do Patrimônio Natural Emílio Fiorentino Batistela, in Corupá $\left(26^{\circ} 25^{\prime} 45^{\prime \prime} \mathrm{S}, 049^{\circ} 48^{\prime \prime} \mathrm{W}\right.$, Datum SAD 69, Fig. 1). The Reserva is located on the hillsides of the Serra Geral, and the altitude of the sampling area averages $265 \mathrm{~m}$ above sea level. Area II corresponds to the surroundings of the Centro de Estudos e Pesquisas Ambientais (CEPA) Rugendas, belonging to the Universidade Regional de Joinville, São Bento do Sul $\left(26^{\circ} 03^{\prime} 00^{\prime \prime} \mathrm{S}\right.$, $049^{\circ} 03^{\prime} 00^{\prime \prime}$ W, Datum SAD 69, Fig. 1), average elevation of this area is $800 \mathrm{~m}$ above sea level. According to phytogeographic classification, both areas are inserted within the Atlantic Forest Biome, area I is located on submontane ombrophilous dense forest and area II is located on montane ombrophilous dense forest (IBGE 2012). Based on the Köppen classification, the climate in both areas is Cfa-type, humid subtropical climate without dry season set (Alvares et al. 2013).

Seventeen morphological measurements were obtained from specimens using a digital calipter: $\mathrm{FA}=$ forearm size, GLS = total length of skull, CIL = condyle incisive length, $\mathrm{CCL}=$ condyle canine length, $\mathrm{BB}$ $=$ width of the braincase, $\mathrm{ZB}=$ zygomatic width, $\mathrm{PB}=$ Postorbital breadth, C-C = Palatal width at canines, PL $=$ Palatal length, $\mathrm{MTRL}=$ Length of the series of teeth of the maxilla, MLTRL = Length of the molars, M1-M1 =
Width between M1, M2-M2 = Width between M2, MB = Mastoid width, $\mathrm{COH}=$ Coronoid height, $\mathrm{DENL}=$ Tooth length, and MANDL = Length of series of teeth of the mandible (Table 1). All measurements are presented in millimeters and follow Velazco and Simmons (2011). Voucher specimens were prepared and deposited in the Coleção Zoológica da Universidade Regional de Blumenau (CZFURB). The authorization for performing the studies was issued by SISBIO under the number 26934-1. All procedures being performed according to protocols of the American Society of Mastozoology for the use of mammals in research (Sikes et al. 2011).

\section{Results}

Three individuals of Vampyrodes caraccioli were captured in the northern region of Santa Catarina. One female caught on 23 August 2012 (SLA3481, Fig. 2) and 1 male caught on 11 November 2012 (SLA3796) were captured in area I. The specimen captured in area II was a female caught on 27 June 2015 (SLA5623).

The identification of the collected specimens was made using the key provided by Lim and Engstron (2001), Gardner (2008a), Velazco and Simmons (2011), and Díaz et al. (2016). The identification of the specimens at the genus level was based on the following characteristics: (1) presence of facial and dorsal stripes, (2) dorsal list starting at the top of the head, extending to the base of the uropatagium, (3) edge of uropatagium with fringe of hairs, (4) incisors upper $2 / 2$, (5) incisors upper no bilobates, (6) central superior incisors, twice as large as the lateral incisors, (7) molars $2 / 3$, and (8) second molar superior equal to or smaller in size when compared to the first molar. Identification at the species level was based on the observation of the following characters: (1) metacarpal III longer than metacarpal V, (2) U-inverted shape on the posterior edge of the uropatagium, (3) dense and short fur $(<2 \mathrm{~mm})$ on the edge of the uropatagium, (4) parietal foramen well separated from the nuchal crest, (5) presence of little developed groove between the occipital condyle and the paracondylar process, (6) paroccipital process well developed, (7) I1 well developed and bilobed, (8) inferior incisors robust and bilobed, and (9) accessory lingual cusp in $\mathrm{p} 4$.

\section{Discussion}

The records reported here extend the distribution of $V$. caraccioli by $170 \mathrm{~km}$, making it the new limit of the southern distribution for this species. This species has been recorded for the Atlantic Forest biome in the northeast (Faria 2006), southeast (Lourenço et al. 2010, Velazco et al. 2010, Souza et al. 2015) and recently in the south region of Brazil, in Paraná state, with this being the austral limit known for this species (Carvalho et al. 2014). Studies about the fauna of bats for the state of Santa Catarina had not listed $V$. caraccioli (Cherem et al. 2004, Passos et al. 2010) and this study also represents the 


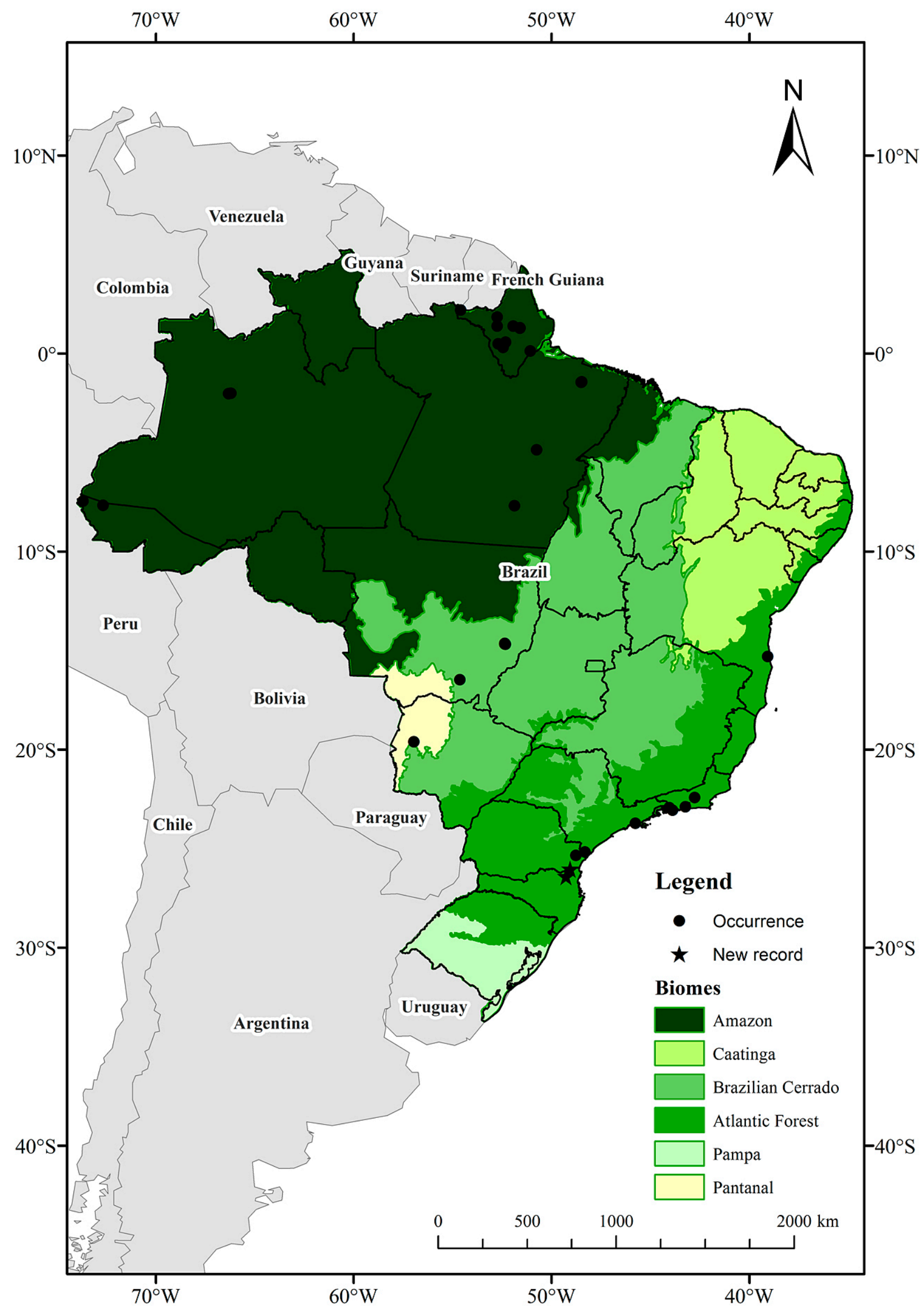

Figure 1. Distribution of Vampyrodes caraccioli records in Brazil reported by Lopes et al. (2016) (dot) and new occurrence records of the species in northern Santa Catarina state, south of Brazil (star). 

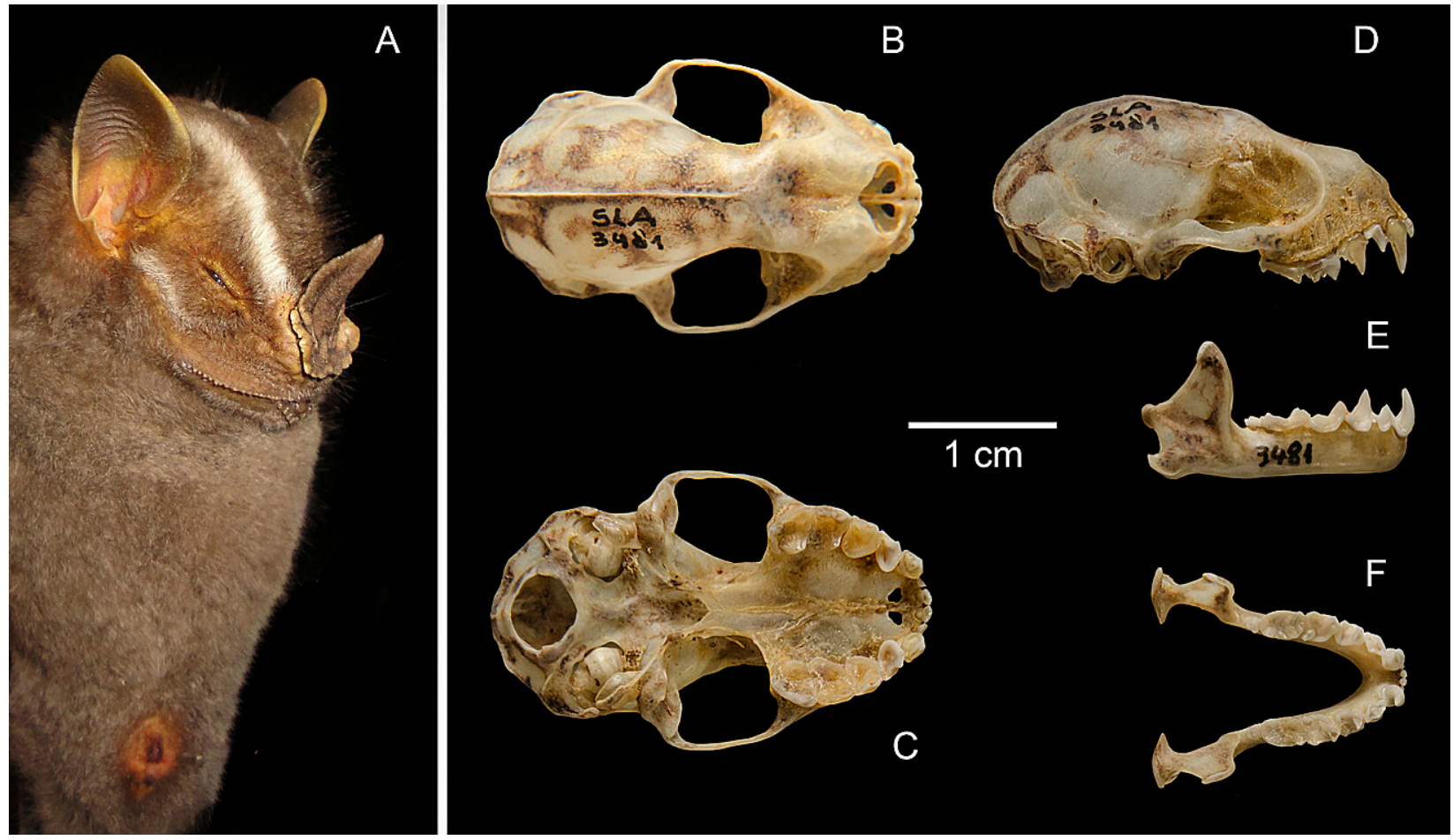

Figure 2. A. Specimen of Vampyrodes caraccioli (SLA 3481 ) ), captured in city of Corupá, in north Santa Catarina state. B-F. Dorsal (B), ventral $(C)$, and lateral views of the skull $(D)$ and dorsal $(E)$ and lateral $(F)$ views of the mandible.

first record of this species in the state of Santa Catarina.

Considering the new record of $V$. caraccioli for Santa Catarina, the number of bats species occurring in this state has increased to 50 species (Passos et al. 2010, Carvalho et al. 2011, Cherem and Althoff 2016, Carvalho et al. in press). At least 117 species have been registered to the Atlantic Forest bioma (Varzinczak et al. 2015), 42.7\% of them being recorded in Santa Catarina, turning the state into a hot spot for bat diversity in Brazil. Bats in Santa Catarina belong mainly to Phyllostomidae (19 spp.) and Vespertilionidae (14 spp.) (Passos et al. 2010), which differs from other regions of Brazil, in which Phyllostomidae represents more than $50 \%$ of the total registered species (e.g. Esbérard 2003, Bernard and Fenton 2007, Alho et al. 2011, Carvalho et al. 2013, Felix et al. 2016). The typical temperate climate in the southern region of Brazil can limit the occurrence of tropical bat species, specifically in the southern portion of the Atlantic Forest (Fabián et al. 1999), where at least 24 species of Phyllostomidae have their southern limits of distribution (e.g. Gardner 2008b).

Among the 17 morphological measurements obtained from the 3 specimens reported here, values obtained for 14 of them were above the variation range described in the literature for Vampyrodes caraccioli (Velazco et al. 2010, Velazco and Simmons 2011). These data reinforce the hypothesis of clinal variation occurrence for this species (Carvalho et al. 2014), although the confirmation of clinal variation is only possible through the analysis of many individuals (Scultori et al. 2009c). Even though the area-volume relation is used to explain the increase in body size of several taxa of mammals in areas of high latitude, factors such as availability and size of food resources can also influence in this relation (see $\mathrm{McNab}$ 1971). In Chiroptera, variation in body size between populations of different latitudes has been observed for several species (e.g Tavares and Velazco 2010, Garbino 2011, Moratelli and Oliveira 2011). For almost all measurements, females were larger than males, which could be an indicative of sexual dimorphism for the specimens collected in this study, although Velazco and Simmons (2011) did not observe this dimorphism when a larger number of specimens was analyzed.

The last decades have experienced an increase on the number of published studies about biology and ecology of bats, especially in the North and South of Santa Catarina (e.g. Carvalho et al. 2008, 2009a, b, Cherem et al. 2011, Carvalho et al. 2013). On the other hand, in the west of Santa Catarina few studies have been carried out on the fauna of bats (e.g. Miranda et al. 2007, Cherem and Althoff 2016), even though it is one of the priority regions for studies on the fauna of bats in the state of Santa Catarina. For the Atlantic Forest Domain, the fauna of bats can still be subsampled even in areas with a large sampling effort (Varzinczak et al. 2015). Studies on the composition of the assemblages are still of fundamental importance. Information resulting from these are important for conservation action plans, in addition to aiding in determining the conservation status of the species and its biology.

\section{Acknowledgements}

We thank the Reserva Particular do Patrimônio Natural Emílio Fiorentino Batistela and UNIVILLE for the 
Table 1. Morphological measures of Vampyrodes caraccioli available in literature and of the 3 specimens captured in the northern region of Santa Catarina, southern Brazil. All measurements are presented in millimeters ( $\mathrm{mm})$.

\begin{tabular}{|c|c|c|c|c|c|c|c|c|}
\hline \multirow{3}{*}{ Character } & \multicolumn{2}{|c|}{ Velazco et al. (2010) } & \multirow{2}{*}{\multicolumn{2}{|c|}{$\begin{array}{c}\text { Velazco and Simmons (2011) } \\
(N=55)\end{array}$}} & \multirow{3}{*}{$\begin{array}{c}\text { Carvalho et } \\
\text { al. (2014) } \\
(N=1) \\
\sigma^{x}\end{array}$} & \multicolumn{3}{|c|}{ Present study } \\
\hline & \multirow{2}{*}{ Holotypes } & \multirow{2}{*}{$\begin{array}{c}(N=1) \\
\wp\end{array}$} & & & & $(N=3)$ & & \\
\hline & & & 운 & $\sigma^{x}$ & & ९ SLA3481 & ९ SLA3796 & o' SLA5623 \\
\hline FA & 49.70 & 54.03 & $47.28-55.98$ & $48.79-53.96$ & 53.9 & 55.9 & 56.0 & 53.3 \\
\hline GLS & - & 28.3 & $25.22-27.97$ & $24.14-27.56$ & 29.1 & 29.11 & 29.48 & 28.89 \\
\hline $\mathrm{CIL}$ & - & 25.83 & $22.54-25.40$ & $22.99-25.34$ & 25.1 & 26.03 & 26.35 & 25.69 \\
\hline$C C L$ & - & 25.17 & $21.98-24.98$ & $22.58-24.66$ & 24.6 & 25.35 & 25.72 & 25.01 \\
\hline BB & - & 10.98 & $10.88-11.91$ & $10.90-11.94$ & 11.9 & 11.90 & 11.99 & 11.82 \\
\hline ZB & - & 17.79 & $15.92-17.89$ & $15.76-17.62$ & 18.3 & 18.53 & 18.80 & 17.93 \\
\hline PB & 6.10 & 6.55 & $5.87-6.79$ & $5.99-6.69$ & 6.2 & 6.72 & 6.83 & 6.56 \\
\hline $\mathrm{C}-\mathrm{C}$ & 6.30 & 6.7 & $6.13-7.08$ & $6.26-6.96$ & 6.9 & 7.36 & 7.43 & 7.19 \\
\hline $\mathrm{PL}$ & 12.45 & 14.14 & $12.25-14.39$ & $12.99-14.46$ & 13.1 & 14.04 & 14.14 & 14.05 \\
\hline MTRL & 9.50 & 10.37 & $9.23-10.25$ & $9.34-9.94$ & 10 & 10.16 & 10.62 & 10.07 \\
\hline MLTRL & 7.85 & 8.88 & $7.71-8.77$ & $7.55-8.43$ & 8.3 & 8.61 & 8.71 & 8.54 \\
\hline M1-M1 & 11.00 & 12.26 & $10.78-12.28$ & $10.64-12.22$ & 12.5 & 12.92 & 13.23 & 12.69 \\
\hline M2-M2 & 11.20 & 12.71 & $11.23-12.37$ & $11.17-12.37$ & 12.8 & 13.44 & 13.70 & 12.96 \\
\hline MB & - & - & $11.78-13.24$ & $11.57-12.80$ & 12.9 & 13.30 & 13.39 & 13.09 \\
\hline $\mathrm{COH}$ & - & - & $7.13-8.28$ & $7.28-8.23$ & 8.6 & 9.08 & 9.23 & 8.91 \\
\hline DENL & 17.35 & 19.32 & $16.91-19.10$ & $17.12-19.07$ & 19.1 & 19.45 & 19.76 & 18.82 \\
\hline MANDL & 10.50 & 11.45 & $10.04-11.27$ & $10.06-11.27$ & 11.1 & 11.58 & 11.68 & 11.22 \\
\hline
\end{tabular}

hospitality of the locals. We are especially grateful to Sidnei S. Dornelles (UNIVILLE) and Gustavo P. C. Fontes (FURB) for the field assistance. We thank Elizabeth Rachenberg your help in laboratory work. Thanks to Sidney Stürmer for critical reading and review of English. Thanks to Jader Lima Pereira (UNESC) for the preparation of the map. Thanks to FURB for the award of a scholarship (PIBIC) and Santa Catarina Secretary of Education, FUMDES art.171. Thanks to the ICMBIO/ SISBIO for the collecting license.

\section{Authors' Contributions}

BT, MARF, MJR and SLA collected the data and did the analysis; BT, FC and SLA wrote the text and did the analysis.

\section{References}

Alho CJR, Fischer E, Oliveira-Pissini LF, Santos CF (2011) Bat-species richness in the Pantanal floodplain and its surrounding uplands. Brazilian Journal of Biology 71 (1): 311-320.

Alvares CA, Stape JL, Sentelhas PC, De Moraes G, Leonardo L, Sparovek G (2013) Köppen's climate classification map for Brazil. Meteorologische Zeitschrift 22(6): 711-728. https://doi. org/10.1127/0941-2948/2013/0507

Basílio GHN, Araujo JPM, Mena JCV, Rocha PA, Kramer MAF (2017) Chrotopterus auritus (Peters, 1856) (Chiroptera, Phyllostomidae): first record for the state of Rio Grande do Norte, northeastern Brazil. Check List 13 (3): 2110. https://doi.org/10.15560/13.3.2110

Bernard E, Fenton MB (2007) Bats in a fragmented landscape: Species composition, diversity and habitat interactions in savannas of Santarém, Central Amazonia, Brazil. Biological Conservation 34: 332-343.

Carvalho F, Cruz-Neto AP, Zocche JJ (2008) Ampliação da distribuição e descrição da dieta de Mimon bennettii (Phyllostomidae, Phyllostominae) no sul do Brasil. Chiroptera Neotropical 14 (2): 403-407.
Carvalho F, Bôlla DAS, Patel FM, Miranda JMD, Althoff SL, Zocche JJ (in press) Ampliação do limite leste de distribuição de Eumops Patagonicus Thomas, 1924 (Chiroptera: Molossidae). Mastozoología Neotropical.

Carvalho F, Fabián ME (2011) Mammalia, Chiroptera, Phyllostomidae, Platyrrhinus recifinus (O. Thomas, 1901): First confirmed record in the state of Santa Catarina, southern Brazil. CheckList 7 (2): 139-141. https://doi.org/10.15560/7.2.139

Carvalho F, Zocche JJ, Mendonça RA (2009a) Morcegos (Mammalia, Chiroptera) em restinga no município de Jaguaruna, sul de Santa Catarina, Brasil. Biotemas 22 (3): 193-201. https://doi. org/10.5007/2175-7925.2009v22n3p193

Carvalho F, Fabián ME, Menegheti JO (2013) Vertical structure of an assemblage of bats (Mammalia: Chiroptera) in a fragment of Atlantic Forest in Southern Brazil. Zoologia 30 (5): 491-498. https://doi. org/10.1590/S1984-46702013000500004

Carvalho F, Fabián ME, Mendonça RA (2009b) Nota sobre o consumo de frutos de Billbergia zebrina (Bromeliaceae) por Sturnira lilium (Chiroptera: Phyllostomidae) no sul do Brasil. Chiroptera Neotropical 15 (2): 482-486.

Carvalho F, Mottin V, Miranda JMD, Passos FC (2014) First record of Vampyrodes caraccioli (Thomas, 1889) (Chiroptera Phyllostomidae) for the state of Paraná, and range extension to southern region of Brazil. Check List 10 (5): 1189-1194. https://doi.org/ 10.15560/10.5.1189

Cherem JJ, Althoff SL (2016) Mamíferos de uma área de estepe ombrófila nos estados de Paraná e Santa Catarina, Sul do Brasil. Boletim da Sociedade Brasileira de Mastozoologia 73: 42-50.

Cherem JJ, Graipel ME, Tortato M, Althoff SL, Matos FBJ, Voltolini JC, Freitas R, Illenseer R, Hoffman F, Ghizoni-Jr IR, Bevilacqua A, Reinicke R, Salvador CH, Filippini A, Furnari N, Abati K, Moraes M, Moreira T, Oliveira-Santos LGR, Kuhnen V, Maccarini T, Goulart F, Mozerle H, Fantacini F, Dias D, Penedo-Ferreira R, Vieira BP, Simões-Lopes PC (2011) Mastofauna terrestre do Parque Estadual da Serra do tabuleiro, Estado de Santa Catarina, Sul do Brasil. Biotemas 24 (3): 73-84. https://doi.org/10.5007/2175$-7925.2011 \mathrm{v} 24 \mathrm{n} 3 \mathrm{p} 73$

Cherem JJ, Simões-Lopes PC, Althoff SL, Graipel ME (2004) Lista dos mamíferos do Estado de Santa Catarina, sul do Brasil. Mastozoología Neotropical 11 (2): 151-184. 
Dias D, Esbérard CEL, Moratelli R (2013) A new species of Lonchophylla (Chiroptera, Phyllostomidae) from the Atlantic Forest of southeastern Brazil, with comments on L. bokermanni. Zootaxa 3722 (3): 347-360. https://doi.org/10.11646/zootaxa.3722.3.4

Dias D, Esbérard CEL, Moratolli R (2016) Range extension of Lonchophylla peracchii (Chiroptera, Phyllostomidae) to northeastern Brazil. Check List 12 (1): 1841. https://doi.org/10.15560/12.1.1841

Díaz MM, Solari S, Aguirre LF, Aguiar LMS, Barquez RM (2016) Clave de Identificacion de los Murcíelagos de Sudamerica. Publicatión Especial n. 2, Programa de Conservación de los murcíelagos de Argentina (PCMA), Tucumã, 162 pp.

Esbérard CEL (2003) Diversidade de morcegos em área de Mata Atlântica regenerada no sudeste do Brasil. Revista Brasileira de Zoociêncas 5 (2): 189-204.

Fabián ME, Rui AM, Oliveira KP (1999) Distribuição geográfica de morcegos Phyllostomidae (Mammalia: Chiroptera), no Rio Grande do Sul, Brasil. Iheringia 87: 143-156.

Faria D (2006) Phyllostomid bats of a fragmented landscape in the northeastern Atlantic Forest, Brazil. Journal of Tropical Ecology 22: 531-542. https://doi.org/10.1017/S0266467406003385

Feijó JA, Rocha PA, Althoff. SL (2015) New species of Histiotus (Chiroptera: Vespertilionidae) from northeastern Brazil. Zootaxa 4048 (3): 412-427. https://doi.org/10.11646/zootaxa.4048.3.4

Felix S, Novaes RLM, Souza RF, Avilla LS (2016) Bat assemblage in a karstic area from northern Brazil: seven new occurrence for Tocantins state, including the first record of Glophonycteris sylvestris Thomas, 1896 for the Cerrado. Check List 12 (6): 1999. https://doi. org/10.15560/12.6.1999

Garbino GST (2011) Chiroptera, Emballonuridae, Saccopteryx leptura (Schreber, 1774): range extension and first record for the states of São Paulo and Minas Gerais, southeastern Brazil. Check List 7 (3): 319-322. https://doi.org/10.15560/7.3.319

Gardner AL (2008a) Genus Vampyrodes O. Thomas, 1900; In: Gardner AL (Ed) Mammals of South America, Volume 1, Marsupials, Xenarthrans, Shrews, and Bats. The University of Chicago Press, Chicago, 355-357.

Gardner AL (2008b) Mammals of South America, Volume 1, Marsupials, Xenarthrans, Shrews, and Bats. The University of Chicago Press, Chicago, 669 pp.

Gazarini J, Bernardi IP (2007) Mammalia, Chiroptera, Molossidae, Molossops neglectus: First record in the State of Paraná, Brazil. Check List 3 (2): 123-125. https://doi.org/10.15560/3.2.123

Gregorin R, Ditchfield AD (2005) New genus and species of nectarfeeding bat in the tribe Lonchophyllini (Phyllostomidae: Glossophaginae) from northeastern Brazil. Journal of Mammalogy 86 (2): 403-414. https://doi.org/10.1644/BRB-229.1

IBGE (Instituto Brasileiro de Geografia e Estatística) (2012) Manual Técnico da Vegetação Brasileira, 2nd edition. Ministério do Planejamento, Orçamento e Gestão, Rio de Janeiro, 271 pp.

Kalko EKV, Handley CO Jr. (2001) Neotropical bats in the canopy: diversity, community structure, and implications for conservation. Plant Ecology 153: 319-333. https://doi.org/10.1023/A:1017590007861

Lim BK, Engstrom MD (2001) Bat community structure at Iwokrama Forest, Guyana. Journal of Tropical Ecology 17 (5): 647-665. https://doi.org/10.1017/S0266467401001481

Lopes GP, TSantos TCM, Velazco PM (2016) First record of Vampyrodes caraccioli (Thomas, 1889) (Chiroptera, Phyllostomidae) in the state of Amazonas and its updated distribution in Brazil. Check List 12 (3): 1-6. https://doi.org/10.15560/12.3.1909

Lourenço EC, Costa LM, Esbérard CEL (2010) Bat diversity of Ilha da Marambaia, Southern Rio de Janeiro State, Brazil (Chiroptera, Mammalia). Brazilian Journal of Biology 70 (3): 511-519. https:// doi.org/10.1590/S1519-69842010000300007

Martins ACM, Bernard E, Gregorin R (2006) Inventários biológicos rápidos de morcegos (Mammalia, Chiroptera) em três unidades de conservação do Amapá, Brasil. Revista Brasileira de Zoologia 23 (4): 1175-1184. https://doi.org/10.1590/S0101-8175200 6000400026
Martins ACM, Bernard E, Gregorin R, Silva WAS (2011) Filling data gaps on the diversity and distribution of Amazonian bats (Chiroptera): the case of Amapá, easternmost Brazil. Zoologia 28 (2): 177-185. https://doi.org/10.1590/S1984-46702011000200004

Mcnab BK (1971) On the ecological significance of Bergmann's Rule. Ecology 52 (5): 845-854.

Miranda JMD, Bernardi IP, Passos FC (2006) A new species of Eptesicus (Mammalia: Chiroptera: Vespertilionidae) from the Atlantic Forest, Brazil. Zootaxa 1383: 57-68.

Miranda JMD, Azevedo-Barros MFM, Passos FC (2007) First record of Histiotus laephotis Thomas (Chiroptera, Vespertilionidae) from Brazil. Revista Brasileira de Zoologia, 24 (4): 1188-1191. https:// doi.org/10.1590/S0101-81752007000400040

Moratelli R, Dias D (2015) A new species of nectar-feeding bat, genus Lonchophylla, from the Caatinga of Brazil (Chiroptera, Phyllostomidae). Zookeys 514: 73-91. https://doi.org/10.3897/zookeys. 514.10013

Moratelli R, Oliveira JA (2011) Morphometric and morphological variation in South American populations of Myotis albescens (Chiroptera: Vespertilionidae). Zoologia 28 (6): 789-802. https://doi.org/ 10.1590/S1984-46702011000600013

Nogueira MR, Lima IP, Peracchi AL, Simnons NB (2012) New genus and species of nectar-feeding bat from the Atlantic Forest of southeastern Brazil (Chiroptera: Phyllostomidae: Glossophaginae). American Museum Novitates 3747: 1-30. https://doi. org/10.1206/3747.2

Nogueira MR, Lima IP, Moratelli R, Tavares VC, Gregorin R, Peracchi AL (2014) Checklist of Brazilian Bats, with comments on original records. Check List 10 (4): 808-821. https://doi. org/10.15560/10.4.808

Passos FC, Miranda JMD, Bernardi IP, Kaku-Oliveira NY, Munster LC (2010) Morcegos da Região Sul do Brasil: análise comparativa da riqueza de espécies, novos registros e atualizações nomenclaturais (Mammalia, Chiroptera). Iheringia 100 (1): 25-34. https://doi.org/ 10.1590/S0073-47212010000100004.

Peracchi AL, Lima IP, Reis NR, Nogueira MR, Ortencio Filho H (2012) Ordem Chiroptera. In: Reis NR, Peracchi AL, Pedro WA, Lima IP (Eds) Mamíferos do Brasil. Nélio Roberto dos Reis, Londrina, 155-234.

Reis NR, Peracchi AL, Lima IP (2007) Morcegos do Brasil. Nélio Roberto dos Reis, Londrina, 253 pp.

Scultori C, Dias D, Peracchi AL (2009a) Mammalia, Chiroptera, Phyllostomidae, Lampronycteris brachyotis (Dobson, 1879): first record in the state of Paraná, southern Brazil. Check List 5 (4): 872-875. https://doi.org/10.15560/5.4.872

Scultori C, Dias D, Peracchi AL (2009b) Mammalia, Chiroptera, Phyllostomidae, Artibeus cinereus: first record in the state of Paraná, Southern Brazil. Check List 5 (2): 325-329. https://doi. org/10.15560/5.2.325

Scultori C, Dias D, Peracchi AL (2009c) Mammalia, Chiroptera, Phyllostomidae, Platyrrhinus recifinus: first record in the state of Paraná, southern Brazil. Check List 5 (2): 238-242. https://doi. org/10.15560/5.2.238

Sikes RS, Gannon WL, The Animal Care and Use Committee (2011) Guidelines of the American Society of Mammalogists for the use of wild mammals in research. Journal of Mammalogy 92 (1): 235-253.

Souza RF, Novaes RLM, Siqueira AC, Jacob CSG, Santos CEL, Felix S, Ribeiro E, Sant'Anna C, Vrcibradic D, Avilla LS, Sbragia I, Santori RT (2015) Bats (Mammalia, Chiroptera) in a remnant of Atlantic Forest, Rio de Janeiro, southeastern Brazil. Neotropical Biology Conservation 10 (1): 9-14.

Tavares VC, Velazco PM (2010) Platyrrhinus recifinus (Chiroptera: Phyllostomidae). Mammalian Species 42 (859): 119-123. https:// doi.org/10.1644/859.1

Varzinczak LH, Bernardi IP, Passos FC (2015) Is the knowledge of bat distribution in the Atlantic Rainforest suficiente? Comments about new findings and a case study in the Paraná State coastal area, Brazil. Mammalia 80: 263-269. https://doi.org/10.1515/mammalia 


$$
-2014-0130
$$

Velazco PM, Simmons NB (2011) Systematics and taxonomy of great striped-faced bats of the genus Vampyrodes Thomas, 1900 (Chiroptera: Phyllostomidae). American Museum Novitates 3710: 1-35. https://doi.org/10.1206/3710.2

Velazco PM, Aires CC, Carmignotto AP, Bezerra AMR (2010) Mammalia, Chiroptera, Phyllostomidae, Vampyrodes caraccioli (Thomas, 1889): range extension and revised distribution map. Check List 6 (1): 49-51. https://doi.org/10.15560/6.1.049

Weber MM, Arruda JL, Cáceres NC (2006) Ampliação da distribuição de quatro espécies de morcegos (Mammalia, Chiroptera) no Rio
Grande do Sul, Brasil. Biota Neotropical 7 (2): 293-296. https:// doi.org/10.1590/S1676-06032007000200032

Willis KB, Willig MR, Jones JK (1990) Vampyrodes caraccioli. Mammalian Species 359: 1-4. https://doi.org/10.2307/3504287

Zortéa M (2007) Subfamília Stenodermatinae. In: Reis NR, Peracchi AL, Pedro WA, Lima IP (Eds) Morcegos do Brasil. Nélio Roberto dos Reis, Londrina, 107-128.

Zortéa M, Zenha FSM, Carrijo VA (2013) The occurrence of Eptesicus chiriquinus Thomas, 1920 (Chiroptera: Vespertilionidae) in the Brazilian Atlantic Forest with comments on the species' distribution. Check List 9 (3): 672-674. https://doi.org/10.15560/9.3.672 